\title{
HYDROLOGIC CHANGES ASSOCIATED \\ WITH THE \\ LOMA PRIETA EARTHQUAKE \\ IN THE \\ SAN LORENZO AND PESCADERO DRAINAGE BASINS
}

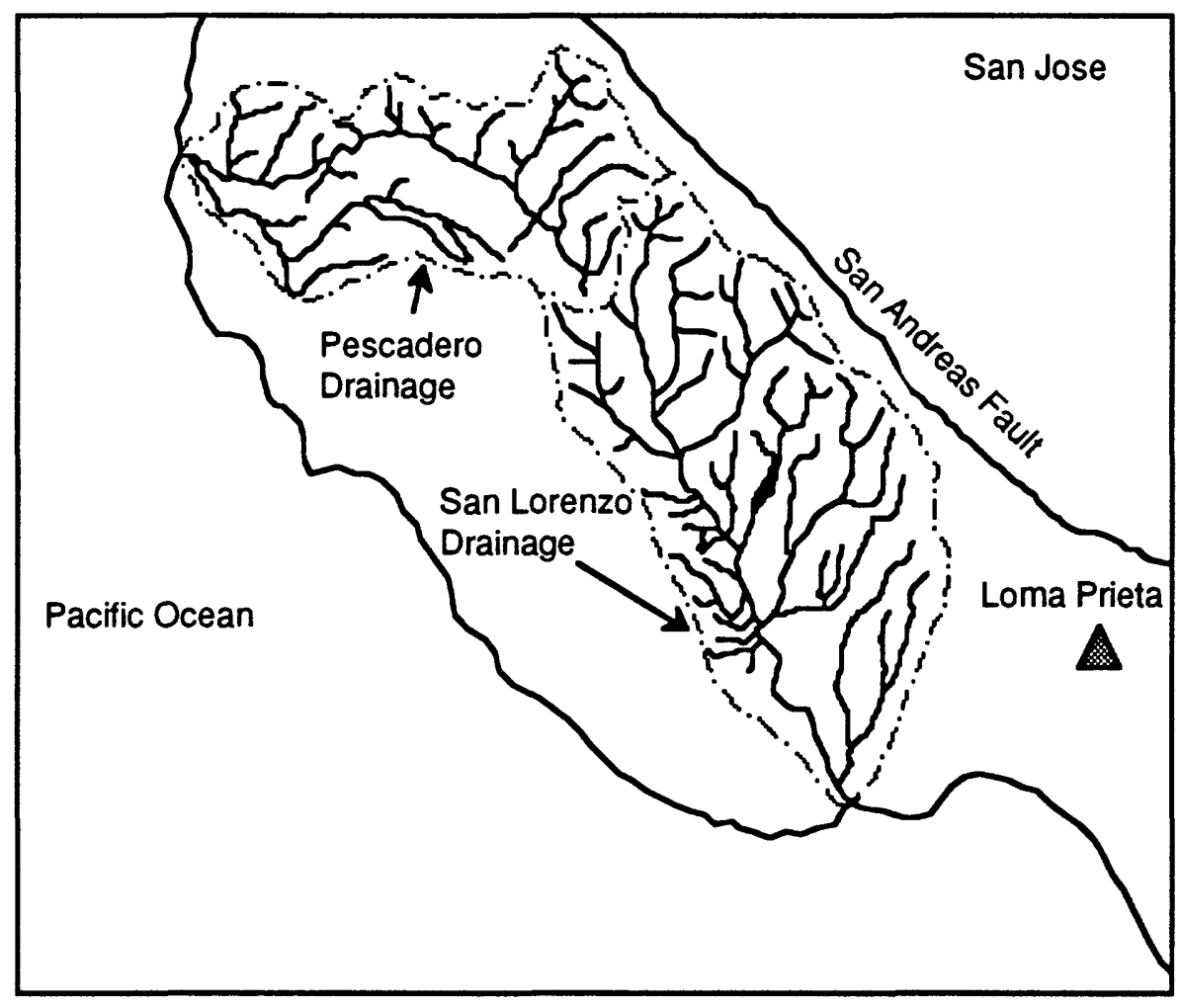

\section{U.S. DEPARTMENT OF THE INTERIOR \\ U.S. GEOLOGICAL SURVEY \\ Open File Report 91-567}

This report is preliminary and has not been reviewed for conformity with U.S. Geological Survey editorial standards (or with the North American Stratigraphic Code). Any use of trade, product, or firm names is for descriptive purposes only and does not imply endorsement by the U.S. Government. 


\title{
U.S. DEPARTMENT OF THE INTERIOR
}

\section{U.S. GEOLOGICAL SURVEY}

\section{Hydrologic Changes Associated with the Loma Prieta Earthquake in the San Lorenzo and Pescadero Drainage Basins}

\author{
by \\ Stuart Rojstaczer ${ }^{1}$ \\ \&
}

Stephen Wolf ${ }^{2}$

Open-File Report 91-567

This report is preliminary and has not been reviewed for conformity with U.S. Geological Survey editorial standards (or with the North American Stratigraphic Code). Any use of trade, product, or firm names is for descriptive purposes only and does not imply endorsement by the U.S. Government.

1 Presently at Department of Geology, Duke University, Durham, NC 27706

2 U.S. Geological Survey, M.S. 988, 345 Middlefield Rd., Menlo Park, CA 94025 


\title{
CONTENTS
}

\author{
Abstract 1 \\ Introduction 2 \\ Description of study area 4 \\ Streamflow response to Loma Prieta 4 \\ Groundwater response 12 \\ Possible causes of response 15 \\ A simple diffusional model of hydrologic response $\quad 17$ \\ Conclusions 18 \\ Acknowledgments 19 \\ References cited $\mathbf{2 0}$
}




\section{FIGURES}

1. Map showing location of study area in relation to San Andreas fault, the Loma Prieta epicenter, and the northern portion of the Loma Prieta rupture zone 3

2-8. Graphs showing:

2. Hydrograph of San Lorenzo Park from 7/84-7/90 and accompanying record of daily precipitation 5

3. Streamflow response to the Loma Prieta earthquake (10/17/89) at Big Trees, Pescadero and San Lorenzo Park; and at Bear, Boulder and Zayante 6

4. Comparison of mean daily streamflow over the time periods $7 / 88-7 / 89$ and 7/89-7/90 at Big Trees, Pescadero and San Lorenzo Park 8,9

5. Base flow as a function of time at the gaging stations 10

6. Total annual flow vs. precipitation at the six stations 10

7. Major ion stream chemistry as a function of time and streamflow at San Lorenzo Park and Big Trees 11, 12

8. Water table elevation as a function of precipitation over the time period 1976-1990 in a well on the eastern edge of the Pescadero basin 13

9. Map showing impact of the Loma Prieta earthquake on wells in the Pescadero headwaters and San Lorenzo headwaters areas 14, 15

\section{TABLES}

1. Mean annual base flow $7 / 1 / 88-7 / 1 / 89$ in relation to drainage area at the 6 gaging stations 5 


\begin{abstract}
The Loma Prieta earthquake (10/17/89, M 7.1) caused significant changes in the hydrology of the San Lorenzo and Pescadero drainage basins. Streamflow increased at most gaging stations within 15 minutes after the earthquake. Ionic concentrations and the calcite saturation index of the stream water also increased. Streamflow and solute concentrations decayed significantly over a period of several months following the earthquake. Groundwater levels in the highlands portions of the basins were locally lowered by as much as $21 \mathrm{~m}$ within weeks to months after the earthquake. The spatial and temporal character of the hydrologic response suggests that the earthquake increased rock permeability and temporarily enhanced groundwater flow rates in the region.
\end{abstract}




\section{INTRODUCTION}

Hydrologic changes associated with moderate and large earthquakes have long been recognized (Camegie Institution, 1908; La Rocque, 1941). While some changes are associated with the dilatational waves generated by earthquakes and are ephemeral (Eaton and Takasaki, 1959; Cooper and others, 1965; Liu and others, 1989), other changes persist in nature and have less obvious explanations. Post-seismic increases in spring flow and streamflow followed such events as the Arvin-Tehachapi earthquake (M 7.1) of 1952 (Briggs and Troxel, 1955), the Borah Peak earthquake (M 7.0) of 1983 (Whitehead and others, 1985), and the Matsushiro earthquake swarm of 1968 (Nur, 1974); the increases lasted from months to years. Post-seismic changes in groundwater level have also been observed (Waller, 1966; Bell and Katzer, 1987); these changes are often too large to be explained by the static compression or extension induced by the earthquake (Bower and Heaton, 1978).

A variety of mechanisms have been postulated to explain these long term changes in groundwater level and rate of surface discharge. Some studies suggested that these phenomena are intimately related to the earthquake cycle. They have been attributed to the expulsion of over-pressured fluids in the seismogenic zone (Sibson, 1981) and to the collapse of a broad network of pre-earthquake induced dilatant fractures (Nur, 1974). Other studies have suggested that these near surface changes strictly reflect near surface processes. Streamflow and spring flow changes have been attributed to elastic compression of confined aquifers (Wood and others, 1985). Changes of water level in wells may be due to seismically induced ground failure near the borehole (Bredehoeft and others, 1965). Streamflow and groundwater changes have also been related to permeability changes in near surface materials (Waller, 1966; Bell and Katzer, 1987).

If near surface changes in hydrology are directly related to the state of mid-crustal pore fluids or pre-earthquake instabilities, then hydrologic monitoring in areas of active seismicity may provide information on the role of fluids in earthquake generation. Hydrologic monitoring may also be used as an aid in earthquake prediction. If, on the other hand, the hydrologic changes reflect only shallow processes, then hydrologic monitoring tells us little about earthquake generation; however, it provides insight in the rheologic response of shallow earth materials to earthquakes.

The Loma Prieta earthquake (10/17/89, M 7.1) provides a unique opportunity to examine hydrologic changes associated with earthquakes. Long term changes in both surface discharge and groundwater levels were observed in the region after the earthquake. Minor changes were also noted in response to the Lake Elsman earthquake (M 5.2,8/8/89), an event which has been described as a foreshock to the Loma Prieta earthquake (Lisowski and others, 1990). Many of the changes were well documented and their possible origins can be examined in some detail. In this paper we examine surface water and groundwater response of the Pescadero and San Lorenzo drainage basins to the Loma Prieta earthquake. The Pescadero drainage basin is well outside the Loma Prieta rupture zone; most of the San Lorenzo drainage is a minimum of $10 \mathrm{~km}$ outside of the rupture zone (Figure 1). While other nearby drainage basins were effected by the Loma Prieta earthquake, the San Lorenzo and Pescadero drainage basins are particularly worthy of examination because the postseismic response of the groundwater system in portions of their recharge areas can be partially quantified. The San Lorenzo drainage basin is also worth examining because unlike other basins in the region, it contains numerous gaging stations that monitor streamflow (Markham and others, 1988). In this report, we examine the character of the streamflow response. We also examine the spatial and temporal response of groundwater levels in portions of the recharge areas of these basins. Finally, we attempt to relate the 


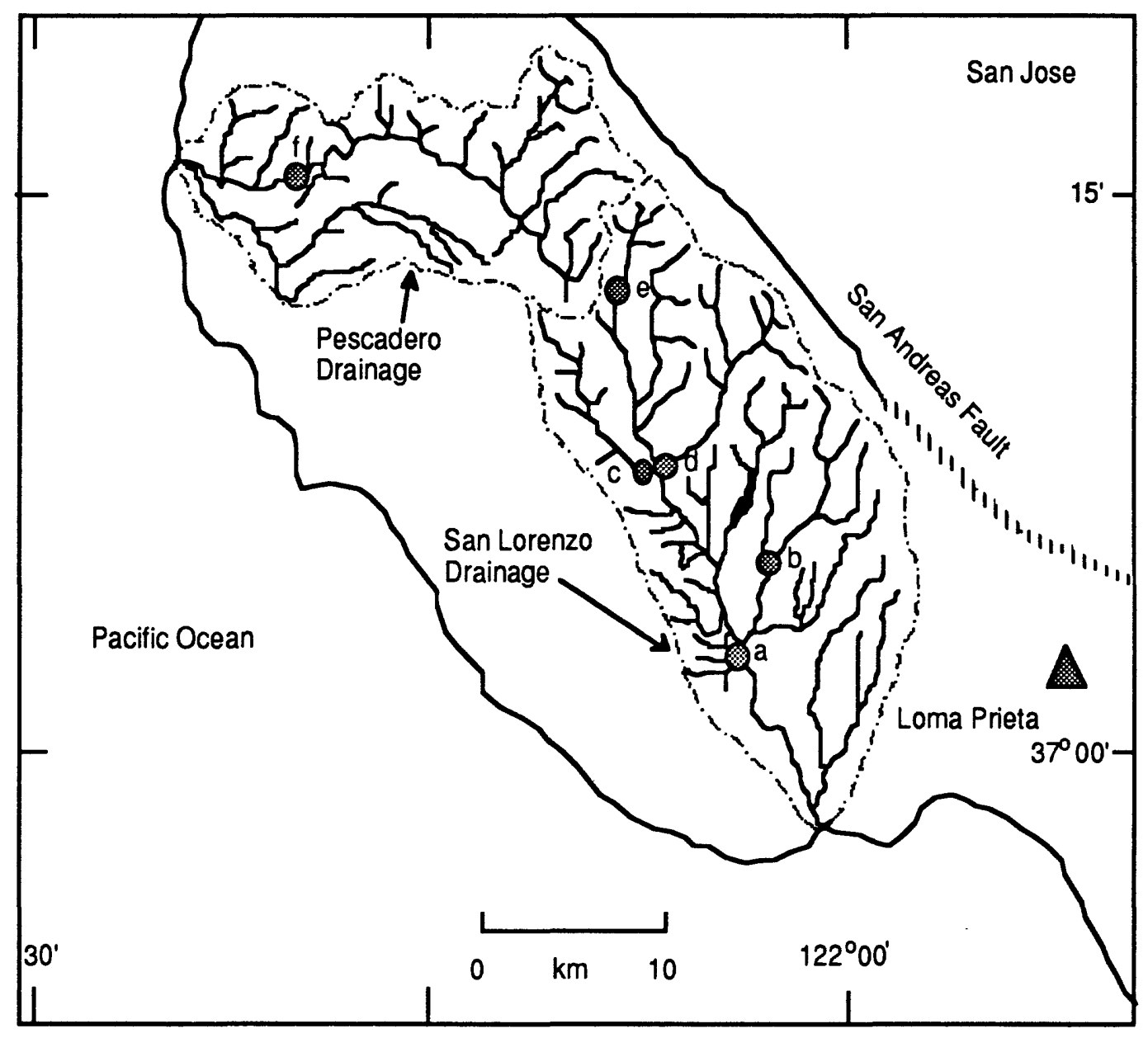

Figure 1. Location of study area in relation to San Andreas fault, the Loma Prieta epicenter (triangle), and the northern portion of the Loma Prieta rupture zone (heavy dashed line). Stream gaging stations (circles) are: $a$ - Big Trees, $b$ - Zayante, c - Boulder, d - Bear, e - San Lorenzo Park, $f$ - Pescadero. 
observed surface and subsurface hydrologic changes to extensive permeability changes within the basins.

\section{DESCRIPTION OF STUDY AREA}

The San Lorenzo and Pescadero drainage basins define a region greater than 600 $\mathbf{k m}^{2}$ in area and are located west of the ruptured segment of the San Andreas fault associated with the Loma Prieta earthquake (Figure 1). The basins are mountainous with slopes commonly exceeding 30 percent. Elevation increases to over $900 \mathrm{~m}$ along the boundary of the basins closest to the San Andreas fault. Stream gradients range from 0.003 to $0.2 \mathrm{~m} / \mathrm{m}$ with the steepest gradients occurring along small low-order tributaries in the extreme upper portions of the drainage basins (Nolan and others, 1984). These small channels are only slightly incised into the surrounding hillslopes, and bedrock exposures are common along such channels. Low order channels usually contain relatively thin deposits of alluvium over the underlying bedrock. Larger intermediate order channels in the middle portions of the watersheds are typically V-shaped and narrow and are incised into the surrounding landscape more than the lower order channels. The channels contain varying amounts of bedrock and characteristically have beds composed of sandy alluvium or boulders surrounded by sandy alluvium. Mean annual rainfall ranges from about 500 mm near the coast to about $1500 \mathrm{~mm}$ in the higher elevations (Rantz, 1971). Rainfall is generally absent from May through September, although fog is common during these months.

Bedrock in the study area consists predominantly of Tertiary marine sandstone, mudstone, shale, as well as some interbedded volcanic units (Clark, 1981). In the high elevations of the basins, the San Lorenzo sandstone, Vaqueros sandstone, and the Lambert shale are the most common bedrock formations and aquifers. These formations are heavily fractured at the surface and the degree to which they are permeable is highly variable and dependent on the degree to which they are fractured at depth (Johnson, 1980; Akers and Jackson, 1977). Stratigraphically beneath the Tertiary marine rocks are Cretaceous granitic and metasedimentary rocks which crop out along the southeastern margin of the San Lorenzo drainage basin. As with the Tertiary rocks, permeability in the Cretaceous units is variable and highly dependent on the degree of fracturing present.

The region contains many extensive zones of structural weakness, both in the near surface and at depth. In the highlands, many ancient and active landslides can be found in the Tertiary formations (Hector, 1976). In addition to the San Andreas fault, major active faults in the basins include the San Gregorio, Butano and perhaps parts of the Zayante (Clark, 1981). Most folds and faults in the area follow the grain of the San Andreas fault and trend northwest-southeast.

\section{STREAMFLOW RESPONSE TO LOMA PRIETA}

Steam flow has been monitored in the region by the U.S. Geological Survey since the 1930's. The stream gaging stations shown in Figure 1 have all been operating for at least 13 years. Regulation and diversion of these rivers and their tributaries is minor upstream of all of the gaging stations (Markham and others, 1988). Mean annual base flow in water year $1989(7 / 1 / 88-7 / 1 / 89)$ at the six gaging stations ranged from 20-500 $\mathrm{J} / \mathrm{s}$ with the amount of base flow generally proportional to the drainage area associated with each gaging station (Table 1). The hydrograph shown in Figure 2 from the San Lorenzo Park station is indicative of the seasonal character of the response at all of the gaging sites. During the dry summer months, streamflow is generally governed by the contribution of groundwater. In the winter months, streamflow is greatly augmented by rainfall-induced 
Table 1. Mean annual base flow $7 / 1 / 88-7 / 1 / 89$ in relation to drainage area at the 6 gaging stations.

\begin{tabular}{lllllll} 
Station & Bear & $\begin{array}{l}\text { Big } \\
\text { Trees }\end{array}$ & Boulder & Pescadero & $\begin{array}{l}\text { San Lorenzo } \\
\text { Park }\end{array}$ & Zayante \\
$\begin{array}{l}\text { Base flow } \\
(1 / \mathrm{s})\end{array}$ & 20 & 400 & 40 & 100 & 20 & 20 \\
$\begin{array}{l}\text { Area } \\
\left(\mathrm{km}^{2}\right)\end{array}$ & 41 & 271 & 29 & 118 & 16 & 28 \\
\hline
\end{tabular}

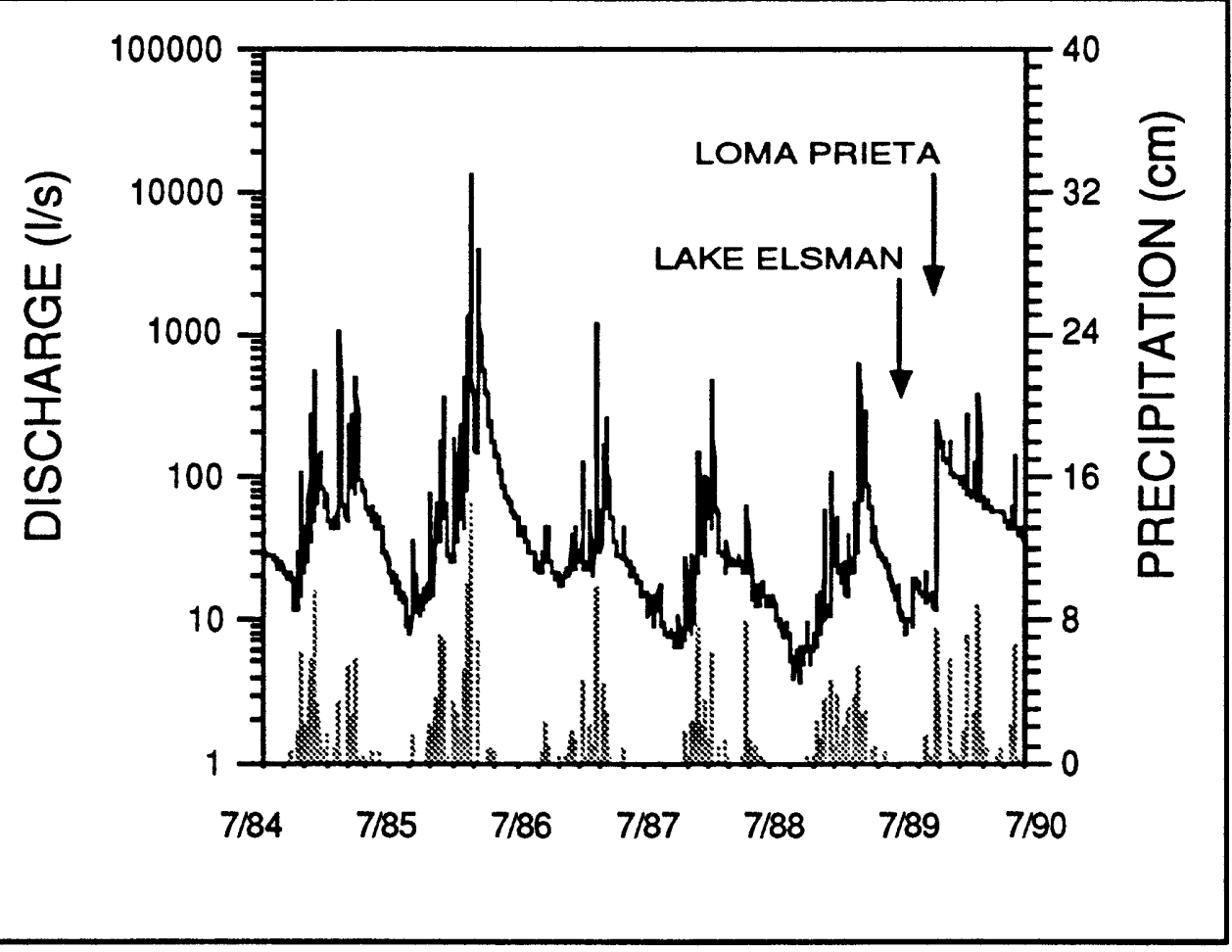

Figure 2. Hydrograph of San Lorenzo Park from 7/84-7/90 and accompanying record of daily precipitation (gray line). 


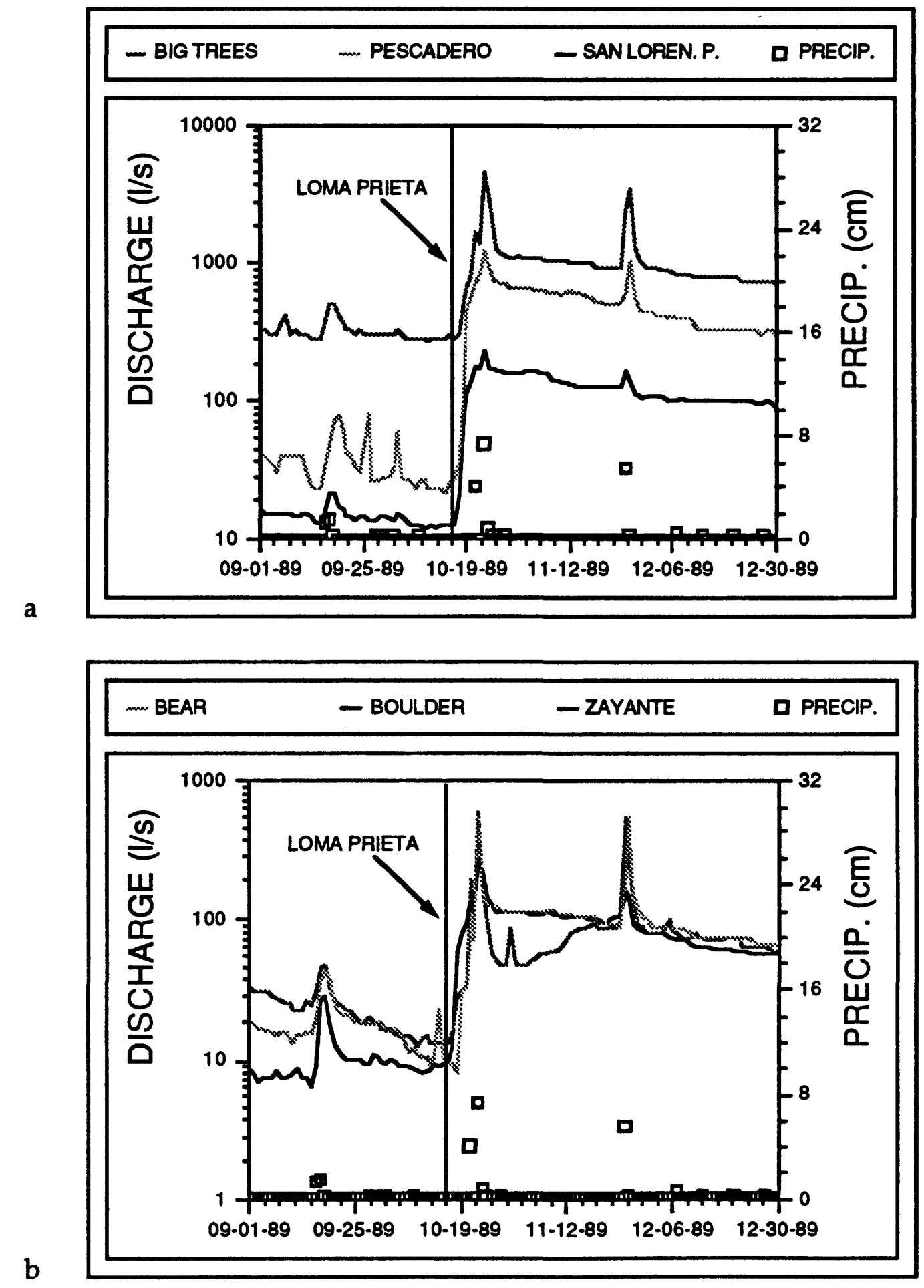

Figure 3. Streamflow response to the Loma Prieta earthquake $(10 / 17 / 89)$ at (a) Big Trees, Pescadero and San Lorenzo Park; (b) Bear, Boulder and Zayante. Streamflow is in terms of a daily mean. Precipitation is in terms of a daily total. 
runoff and interflow. The effects of the Loma Prieta earthquake can be seen as a rapid rise in water level during late October 1989 superimposed on the general seasonal pattern.

In all drainage areas monitored, there is an increase in streamflow associated with the earthquake, indicating the greatly enhanced contribution of groundwater to the streams (Figure 3). Except for the Bear Creek station, streamflow increases were observed at the first sampling following the earthquake (within about 15 minutes of the earthquake) at all stations which were not temporarily disabled by the ground motion. At Bear Creek, streamflow increases were preceded by a post-seismic decrease which persisted for 22 hours. The San Lorenzo Park station was not recording for a period of 70 hours following the earthquake. Streamflow increases were monotonic for several days following the earthquake, but were masked by rain which began on October 21. Peak increases due to the earthquake were generally an order of magnitude greater than pre-quake streamflow. At Big Trees and Boulder Creek, streamflow increases were more modest, indicating that the magnitude of the response was not spatially uniform. There is no coherent relation between the magnitude of streamflow increases and proximity to the rupture area.

Although there were large increases in streamflow due to the earthquake, the long term post-seismic response indicates that these increases were generally short-lived. We estimate the longer term effects of the earthquake on streamflow by comparing the base flow over the period following the earthquake with the base flow of the previous year. Base flow for each year was estimated by straight line hydrograph separation. The excess base flow produced by the earthquake was determined by calculating the difference between the post-earthquake base flow and the base flow one year prior at the same station. This base flow was adjusted by subtracting or adding any differences between the base flow on $10 / 17 / 88$ relative to the base flow on $10 / 17 / 89$. In determining excess base flow, we make the assumption that, independent of the earthquake, streamflow would not vary greatly because the seasonal character and annual amount of precipitation for both years was very similar (72 cm for 1988 and $76 \mathrm{~cm}$ for 1989). For all but the station at Boulder Creek, the difference between base flow on $10 / 17 / 88$ and $10 / 17 / 89$ was less than $10 \%$ of the amount of the excess peak base flow.

The flow at three of the stations from $7 / 1 / 88$ to $7 / 1 / 90$ is shown in Figure 4. The inferred excess flow produced by the earthquake is shown in Figure 5. Excess base flow decays rapidly at all but the Boulder Creek station. After 45 days excess base flow is roughly $1 / 2$ that of peak flow. After 150 days, excess flow is difficult to identify in the records.

The increases in base flow were generally small in comparison to the total annual flow for the year. Figure 6 shows the relation between precipitation and total annual flow at all of the stations for five years of similar total annual rainfall during the previous decade (1984, 1987, 1988, 1989 and 1990). Despite the presence of increased base flow, total streamflow in 1989 decreased at 3 of the stations relative to the previous year. At 2 other stations streamflow increases in 1989 were very small. Only San Lorenzo Park station showed a significant change in total annual flow with an increase of roughly 1 billion liters. This amount of increase is equal to approximately the total amount of inferred earthquake related base flow at this station during this time period. The lack of a significant increase in total flow at most stations indicates that the earthquake did not greatly enhance the surface water supply in this region. For example, the amount of inferred earthquake induced base flow is about $20 \%$ of the total annual flow at Big Trees.

Stream chemistry at two of the stream gaging stations in the San Lorenzo drainage basin (Big Trees and San Lorenzo Park) has been monitored on a biannual basis. The data shown in Figure 7 indicates that at both sites the water chemistry is dominated by calcium 


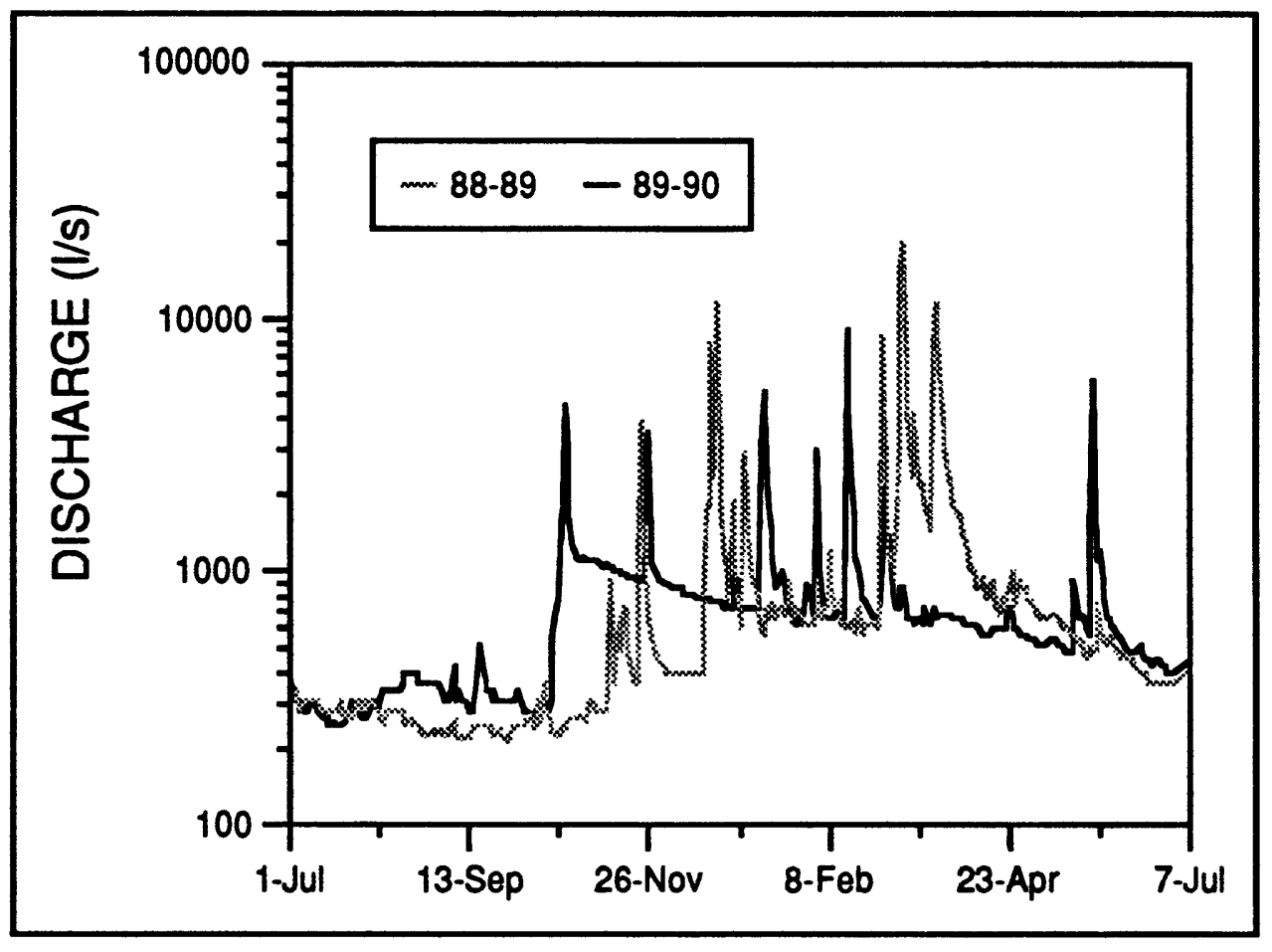

Figure 4a. Comparison of mean daily streamflow over the time periods $7 / 88$ 7/89 and 7/89-7/90 at Big Trees.

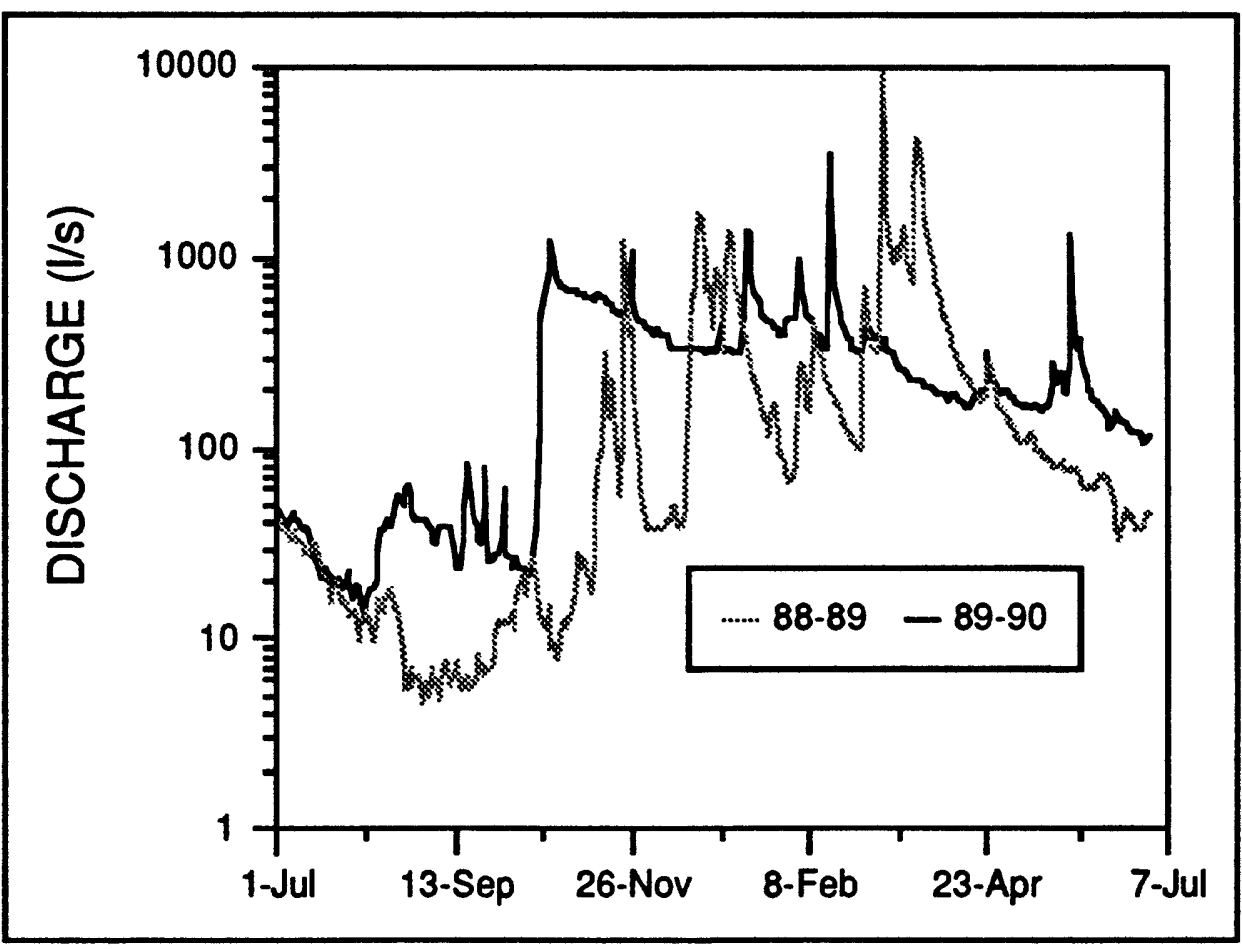

Figure 4b. Comparison of mean daily streamflow over the time periods $7 / 88$ $7 / 89$ and $7 / 89-7 / 90$ at Pescadero. 


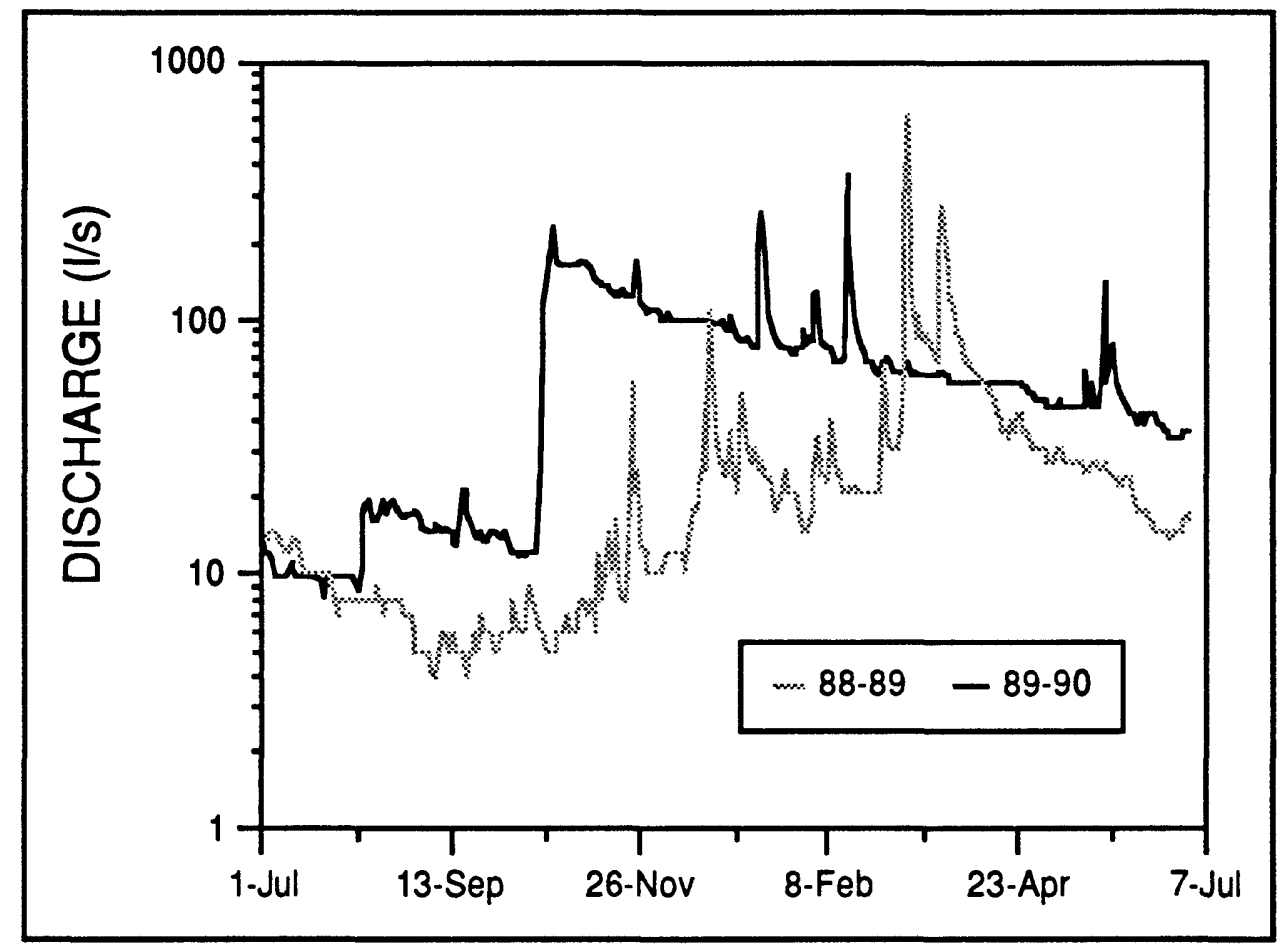

Figure 4c. Comparison of mean daily streamflow over the time periods $7 / 88$ $7 / 89$ and $7 / 89-7 / 90$ at San Lorenzo Park.

and bicarbonate. Hardness and overall ionic concentrations are slightly higher at the San Lorenzo Park gaging station. The differences in water quality between the two sites have been attributed to the geology of the southwestern portion of the San Lorenzo drainage basin (Sylvester and Covay, 1978). The biannual analyses of major ions at the two sites prior to the earthquake suggests that overall concentrations are slightly inversely related to stream discharge rates. The inverse dependence has also been noted in other streams in the region and is likely due to the influence of surface runoff and interflow during winter storms (Steele, 1968; Sylvester and Covay, 1978). The waters are slightly oversaturated with respect to calcite (pre-quake saturation index was 0.4 at both sites). Stream chemistry at these stations is similar to the chemistry of groundwater samples which tap the Vaqueros sandstone and Lambert shale in the highlands of the Soquel-Aptos drainage basin, the neighboring drainage basin to the east (Johnson, 1980).

In response to the earthquake, stream chemistry increased markedly in terms of its overall ionic strength, but the overall proportions of the major ions was nearly the same as under pre-quake conditions. The increase in bicarbonate and calcium caused the calcite saturation index to increase to 0.8 . Water temperature in early November 1989 was 7 degrees $\mathrm{C}$ at both stations, nearly 4 degrees cooler than any previous measurement either in spring or fall. By April 1990, the stream chemistry had begun to approach pre-quake conditions at both locations. The changes in temperature and chemistry suggest that the additional water caused by the earthquake was derived from groundwater from the surrounding highlands. The source rock of the groundwater likely contributed to streamflow before the earthquake, but to a smaller degree. 


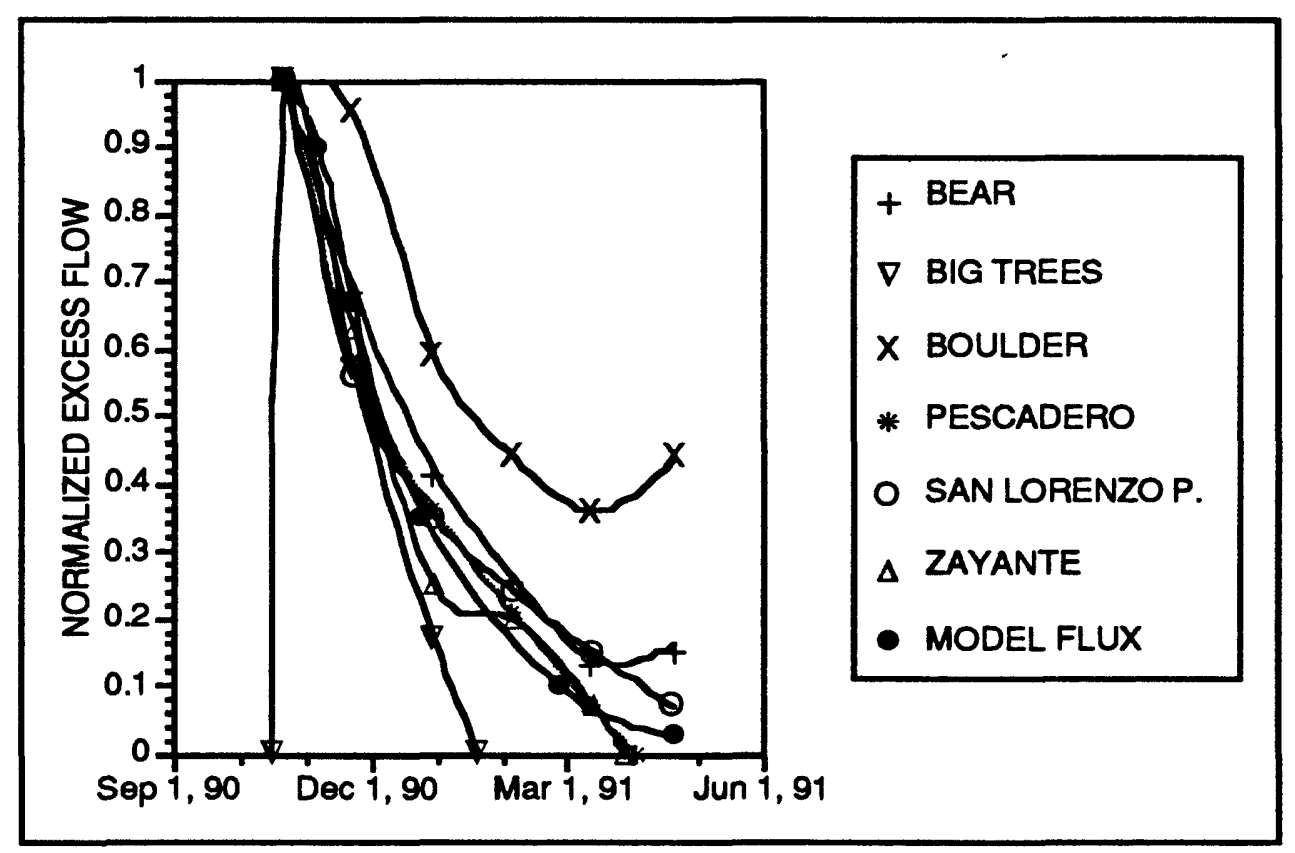

Figure 5. Base flow as a function of time at the gaging stations. Based flow is normalized by the peak excess base flow at each station: Bear, $110 \mathrm{l} / \mathrm{s} ; \mathrm{Big}$ Trees $920 \mathrm{~V} / \mathrm{s}$; Boulder $40 \mathrm{~V} / \mathrm{s}$; Pescadero $690 \mathrm{~V} / \mathrm{s}$; San Lorenzo Park, $170 \mathrm{~V} / \mathrm{s}$; Zayante $110 \mathrm{l} / \mathrm{s}$.

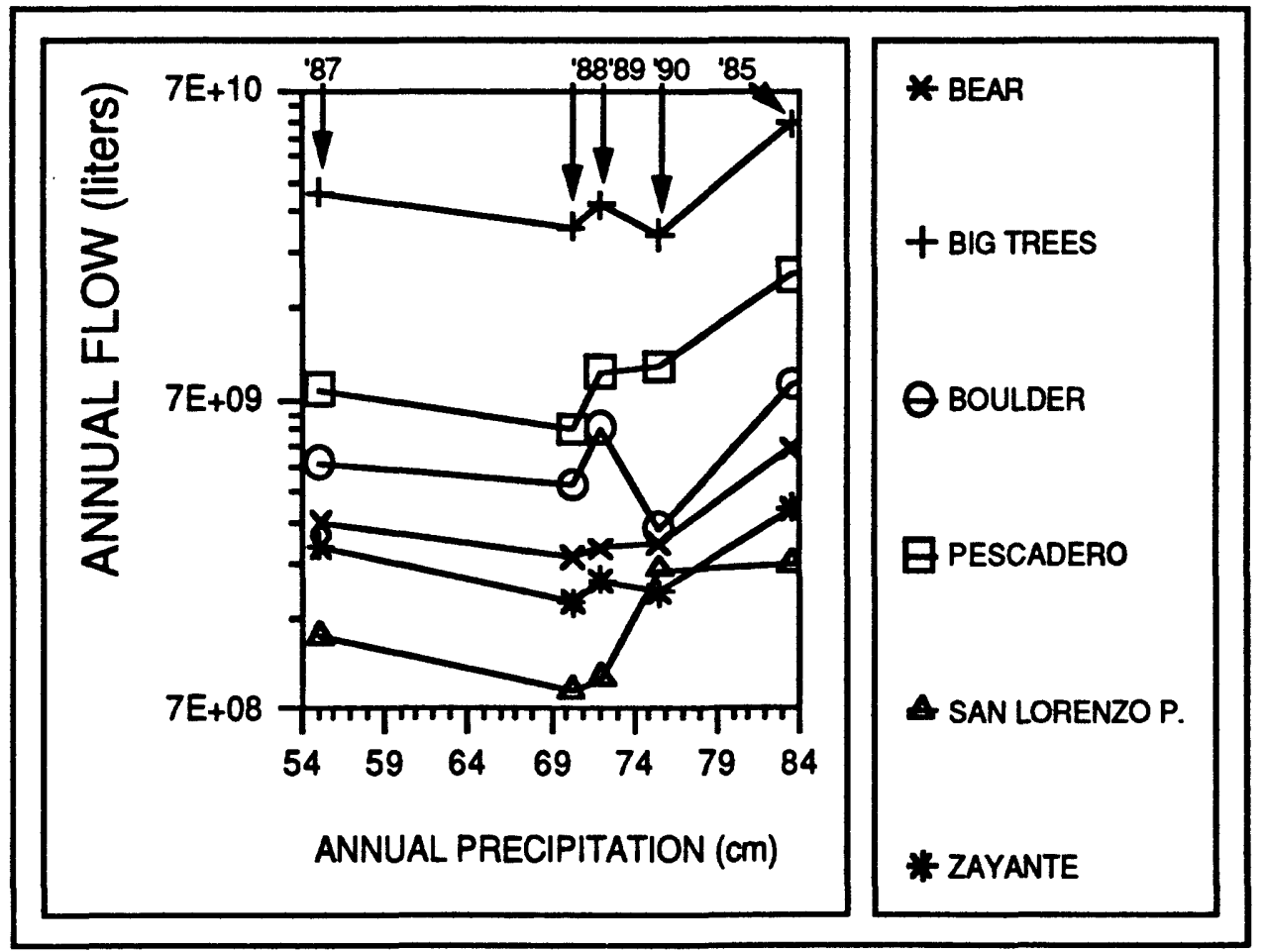

Figure 6. Total annual flow vs. precipitation at the six stations. Years shown in figure are water years (eg., 1989 refers to the water year 7/88-7/89). 


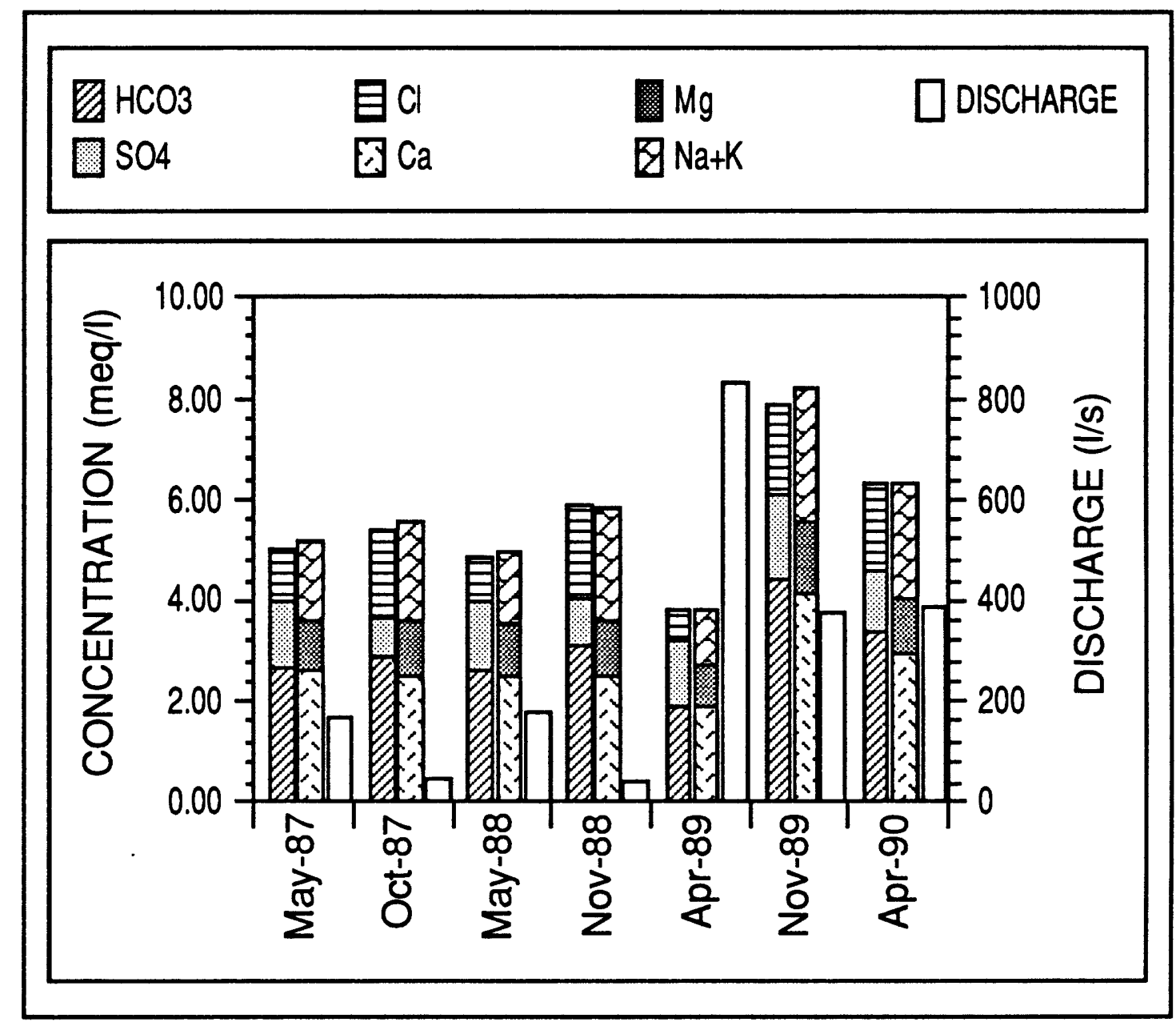

Figure 7a. Major ion stream chemistry as a function of time and streamflow at San Lorenzo Park.

The response of the region is similar, but much larger in extent and magnitude to the Lake Elsman earthquake of August 8, 1989. The earlier earthquake produced a twofold increase in flow at the San Lorenzo Park and Pescadero stations. At the other stations, changes were too small to be detected. The Lake Elsman earthquake of June 27, 1988 (M 5.0) did not cause a detectable change at any of the gaging stations.

Anecdotal reports suggest that in two ungaged streams in basins neighboring the basins of this study, large increases in streamflow preceded the Loma Prieta earthquake by roughly one hour (D. Friend, personal communication; K. Tarkuchi, personal communication). Streamflow is monitored at the stations examined in this report at 15 minute intervals, and pre-quake increases are not detectable in the data. Any precursory changes in streamflow which occurred in ungaged streams were local in extent and not representative of the hydrologic response of the region. 


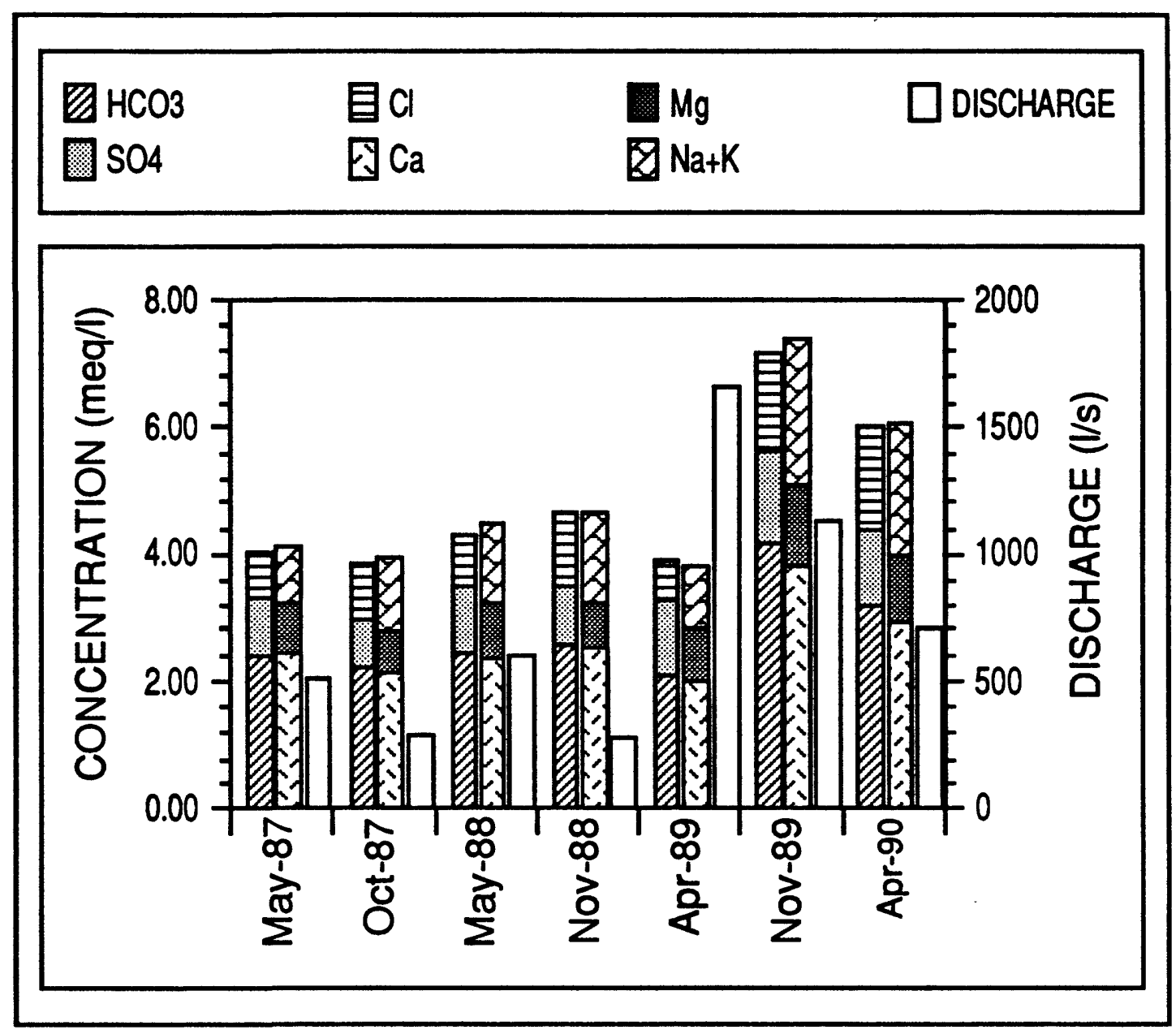

Figure $7 \mathrm{~b}$. Major ion stream chemistry as a function of time and streamflow at Big Trees.

\section{GROUNDWATER RESPONSE}

Groundwater flow in the basins is predominantly controlled by fracture orientation and density. Groundwater is derived from local precipitation and moves downward through fracture networks (Akers and Jackson, 1977). A study of groundwater flow in the neighboring Soquel-Aptos drainage basin indicated that $90 \%$ of all groundwater discharges into local streams and springs (Essaid, 1990). Very little basin derived groundwater flows directly into the ocean. Because the climate and geometry of the basins in this study are similar to that of the Soquel-Aptos basin, it is likely that almost all groundwater flow in the San Lorenzo and Pescadero basins discharges into local streams and springs.

There were numerous anecdotal reports of earthquake related changes in water level and water quality of wells in the study area as well as reports of changes in spring flow. Exact measurements of pre-quake water levels are generally not available in the region. One well which taps an unconfined aquifer located in the eastern headwaters of the Pescadero Creek, has been monitored weekly since 1976 and is shown in Figure 8 (location of the well is shown in Figure 9a). The hydrograph has a strong semi-annual 
cycle. The amplitude of the semi-annual cycle is highly dependent on the amount of rainfall, but is on the order of $5 \mathrm{~m}$ during years of near average rainfall. While the effects of drought have had an influence on the hydrograph, the earthquake caused the water level to drop 4 meters within several weeks following the earthquake.

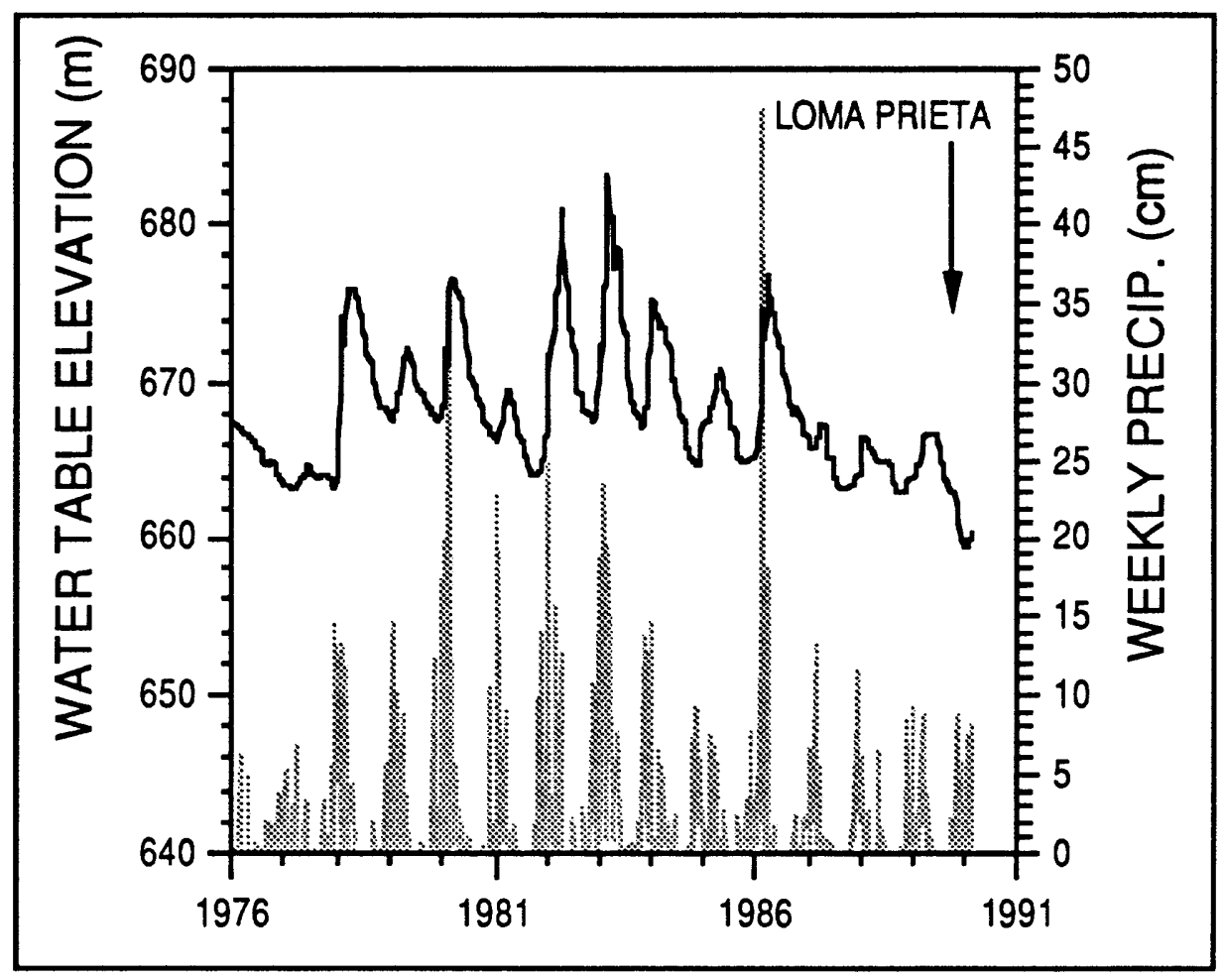

Figure 8. Water table elevation as a function of precipitation over the time period 1976-1990 in a well on the eastern edge of the Pescadero basin. Well is the northern most well in the map of Figure 9a.

Although changes in water level in the recharge areas of these basins are generally difficult to quantify, we infer that similar drops in water level occurred in a significant portion of the basin highlands. There are numerous wells which either went dry or underwent a significant reduction in their capacity to pump water within several weeks after the earthquake. We focus our attention on measured and inferred groundwater level changes in two areas of the Santa Cruz mountains. One area which includes the well noted above, is shown in Figure 9a. This area is located along the crest of the Santa Cruz mountains and straddles the border of the Pescadero drainage basin. The other area near the headwaters of the San Lorenzo River is shown in Figure 9b. These areas were selected due to their well density and the level of cooperation on the part of the landowners. The wells shown in Figure 9 are used by single homes and range in depth from 40 to $140 \mathrm{~m}$.

Of the wells shown in Figure 9a, roughly one-half suffered a reduced capacity to deliver water for home uses or were completely dry by January 1990 . In general, the wells which were most effected were in the southern portion of the area (where elevation is highest). In most of the wells which were adversely affected (wells which either went dry or no longer provided enough water for home use), changes were noted within several weeks after the earthquake. In other affected wells, the changes were gradual and wells 
which became dry did so over a period of 2-3 months. It is difficult to quantitatively relate the adverse impact of the wells to a water table decline. Wells in the region which were not adversely affected generally have water levels which are in excess of $7 \mathrm{~m}$ above the well bottom. If these conditions existed prior to the earthquake in the impacted wells, then the water table declines produced by the earthquake would be on this order or greater.

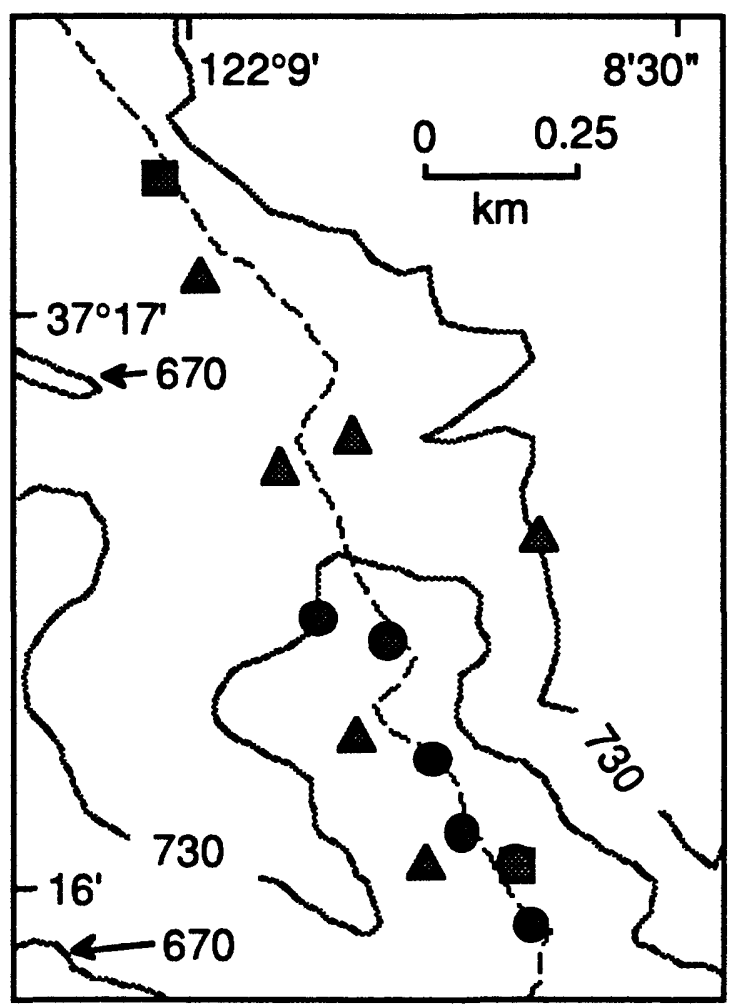

Figure 9a. Impact of the Loma Prieta earthquake on wells in the Pescadero headwaters. Symbols indicate that the well went dry (circle), the well developed a reduced ability to yield water for supply (square), or the well was unaffected (triangle). Elevation contours (light lines) are in meters. Dashed line is boundary of drainage basin.

In the San Lorenzo headwaters area (Figure 9b), wells that are adversely affected were generally confined to two ridge tops. Wells along the northeast edge of the area and wells located near the valley floor were not adversely impacted. Although no extensive pre-quake water level records exist for this area, there is limited anecdotal information on pre-quake levels in some wells. In one well which became dry, the water level was $21 \mathrm{~m}$ above the bottom on 10/11/89. In another well which became dry, the water level was 40 $\mathrm{m}$ above the bottom during $2 / 89$. In two wells whose water levels began to be monitored after October 17, water levels dropped over $20 \mathrm{~m}$ within a period of weeks to months following the earthquake. Subsequent measurements in the region of unaffected and impacted (but not dry) wells over the time period 1/90-7/90 indicated that water levels declined gradually in many wells (on the order of $1.5 \mathrm{~m} /$ month or less). The rates of decline during 1990 are too gradual to be uniquely identified as being due to the Loma Prieta earthquake. They may also be due to the effects of drought in the region. The water 
level data suggest that the impact of the earthquake on groundwater levels in this area had either greatly diminished or had essentially disappeared after several months following the earthquake.

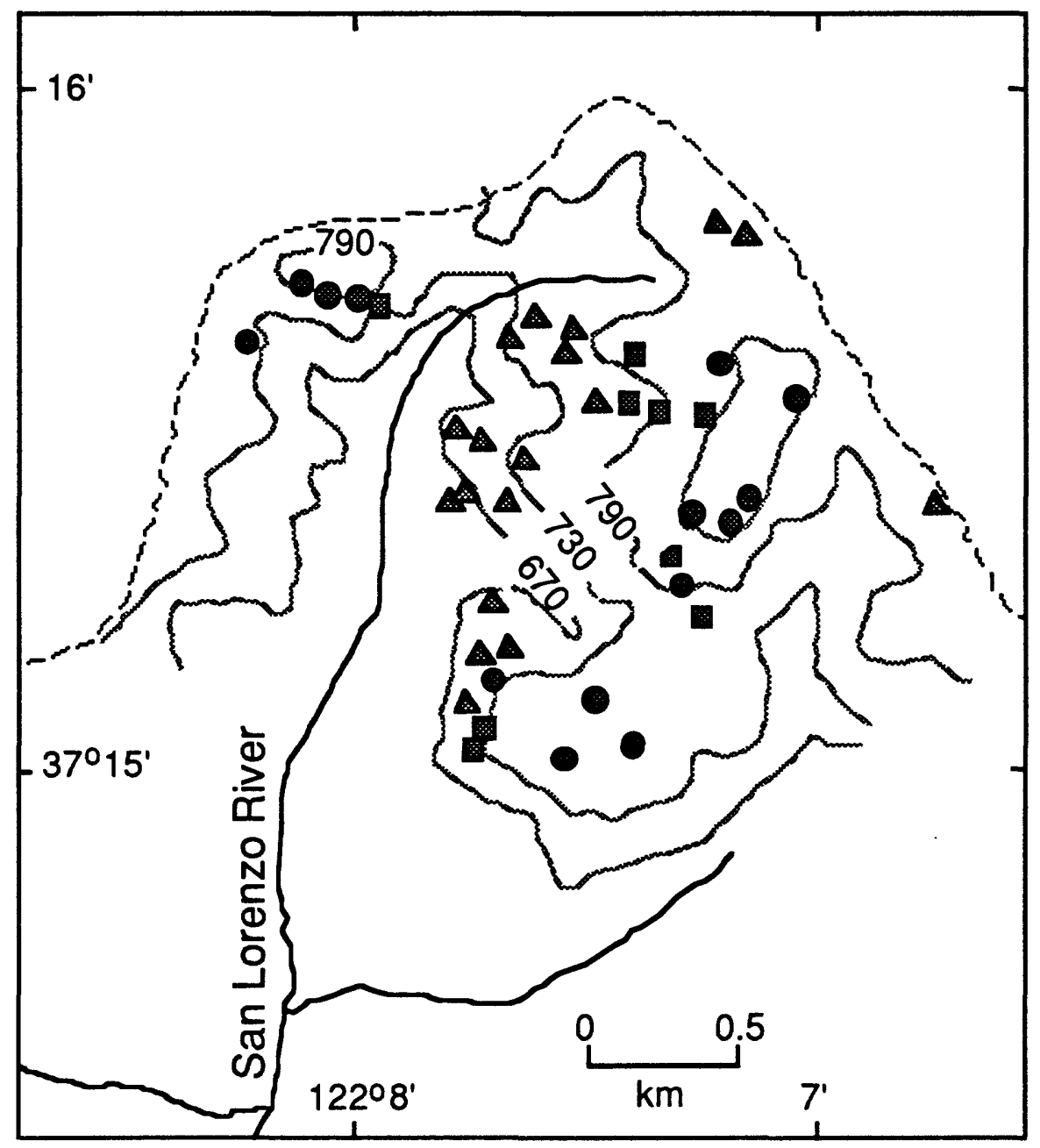

Figure 9b. Impact of the Loma Prieta earthquake on wells in the San Lorenzo headwaters. Symbols indicate that the well went dry (circle), the well developed a reduced ability to yield water for supply (square), or the well was unaffected (triangle). Elevation contours (light lines) are in meters. Dashed line is boundary of drainage basin.

\section{POSSIBLE CAUSES OF RESPONSE}

The observed hydrologic changes (temporary excess streamflow, dropping water table, changes in stream chemistry) are likely due to a common cause. The mechanism responsible produced changes which were spatially non-uniform. Streamflow increases ranged from a factor of 4 to 24 above pre-earthquake conditions and generally decayed rapidly. Water table drops in the areas examined were common but patch-like in extent. The stream chemistry changes indicate that the difference in the excess water was ionic 
strength, not ionic composition. The mechanism which most likely explains the postseismic hydrologic observations is a permeability increase caused by seismically induced fractures and microfractures.

It is difficult to ascribe the observed hydrologic changes to processes occurring at mid-crustal depths. Transport of overpressured fluids from the mid-crust to the surface would require highly permeable vertical pathways at great depth. Streamflow increased at most of the monitoring stations within 15 minutes of the earthquake, indicating that any pore-pressure propagation due to a mid-crustal source would have to travel at a rate on the order of $10 \mathrm{~m} / \mathrm{s}$. Assuming that pore-pressure propagation was a diffusive process, the hydraulic diffusivity of the pathway would have to be impossibly high to allow for such rapid rates of pore-pressure propagation. If, for example, expulsion of over-pressured fluids at depths of $5 \mathrm{~km}$ were responsible for the response of the streams (a rise to peak flow within several days of the earthquake), then the hydraulic diffusivity, $c$, of the pathway would be on the order of $1 \times 10^{6} \mathrm{~cm}^{2} / \mathrm{s}$. This value for hydraulic diffusivity is orders of magnitude above that which has been inferred or observed in the crust (Brace, $1980 ; 1984)$. The mechanism of transport of overpressured fluids is also incompatible with the water table drops observed in the area or the cooler temperature of the stream water.

Collapse of near surface dilatant fractures or squeezing of near surface pore fluids due to static compression induced by the earthquake are also unlikely mechanisms. They run counter to the water table drops seen in the area. They also require an unrealistic amount of pore volume collapse to account for the amount of excess stream discharge. For example, consider the 1 billion liters of earthquake related excess discharge at San Lorenzo Park. If we assume that this excess fluid has its source area in the near surface (to a depth of $200 \mathrm{~m}$ below the water table), then there would have to be compressional strains on the order of $3 \times 10^{-3}$ in this region to account for the excess discharge. This amount of shortening is at least an order of magnitude greater than that which can be inferred from geodetic measurements of the displacements caused by the earthquake (Lisowski and others, 1990).

A mechanism which accounts for both excess discharge and a lowered water table is a wide scale increase in near-surface permeability in the study area. If the fracture networks which control groundwater flow in the region were enhanced due to the earthquake, groundwater flow rates would initially increase in proportion to the permeability increase. The water table would drop because the groundwater system would be effectively drained by the increased discharge. Areas of high elevation would be most susceptible to water table drops because they would tend to have the highest water table elevations prior to the earthquake.

The increased fractures and microfractures in the groundwater system would also be expected to temporarily alter the chemistry of the groundwater. They would tend to expose previously near-stagnant water in small pores to enhanced groundwater flow paths. This near-stagnant pore water, because it has had a great deal of time to interact with rockmineral surfaces, would have a relatively high concentration of solutes. As a result of the generation of new flow paths a greater proportion of high solute concentration water would be expected to enter the major groundwater flow paths and the ionic strength of the exiting groundwater would be increased.

To account for the initial surge in discharge, the fracturing would have to effectively increase the permeability in portions of the aquifers and aquitards in the highlands by roughly an order of magnitude. Streamflow would decay rapidly because the hydraulic 
gradient which drives fluid flow would decay as the water table dropped. The fall in water table height would be expected to decline at a rate similar to the decline of streamflow.

The relatively shallow depth of the water table in the highlands portions of the region suggests that permeability increases and concomitant water table drops are temporary in nature. If they were permanent, the numerous historic and prehistoric earthquakes in the region would likely lower the water table to great depths. Between earthquakes, the fracture networks likely heal and the water table partly recovers to its preearthquake level. We propose that permeability in this region is a time dependent parameter, increasing during times of seismicity and relaxing during inter-seismic periods. The temporal nature of permeability in response to shear strain in the region would be consistent with time dependent variability in permeability in laboratory samples subjected to shear (Kranz and Blacic, 1984). In the laboratory work of Kranz and Blacic the cracks were sealed by silica cementation. Because the base flow is oversaturated with respect to calcite, we speculate that calcite cementation would be a likely mechanism for fracture healing and concomitant permeability reduction. The time constant for this inferred process, however, is not identifiable in this analysis of the data.

\section{A SIMPLE DIFFUSIONAL MODEL OF HYDROLOGIC RESPONSE}

In order to examine the theoretical response of streamflow and groundwater levels to permeability changes, we employ a very simple diffusional model of groundwater flow along a hillside. Prior to the earthquake, the water table increases linearly with distance from the stream at a rate of $0.1 \mathrm{~m} / \mathrm{m}$ and flow rates in the groundwater system are constant. Pre-quake groundwater flow rates can be estimated from the ratio of base flow to area given in Table 1 and are on the order of $1 \times 10^{-7} \mathrm{~cm} / \mathrm{s}$ for all the drainage areas. Employing Darcy's law and assuming the aforementioned water table gradient of 0.1 , yields a bulk pre-quake permeability for the drainage basins of 10 milliDarcies. This permeability estimate is obtained by assuming that the gradient of hydraulic head can be approximated by the gradient of the water table.

Assuming that the earthquake increases permeability by an order of magnitude, the gradient of the water table will decline and the groundwater flow rate into the stream will initially increase by an order of magnitude. The governing equations and boundary conditions for this simple model are:

$$
\begin{aligned}
& \partial^{2} \mathrm{~h} / \partial \mathrm{x}^{2}=\mathrm{c}^{-1} \partial \mathrm{h} / \partial \mathrm{t} \\
& \mathrm{h}(\mathrm{x}, 0)=\mathrm{w}((\mathrm{L}-\mathrm{abs}(\mathrm{x})) / \mathrm{L}) \\
& \mathrm{h}(\mathrm{L}, \mathrm{t})=\mathrm{h}(-\mathrm{L}, \mathrm{t})=0
\end{aligned}
$$

where $h$ is the hydraulic head, $x$ is the horizontal distance, $c$ is the hydraulic diffusivity, $t$ is time, $w$ is the maximum height of the water table relative to the stream and $L$ is the maximum length of the groundwater flow path. Solution of equation 1 and use of Darcy's law yields the groundwater flux, $v$, into the stream as a function of time, $t$ :

$$
v=[4 k \rho g w / \mu L] \sum_{n=0}^{\infty}\left[(-1)^{n /(2 n+1)}\right] \exp \left[-(2 n+1)^{2} \pi^{2} c t /\left(4 L^{2}\right)\right]
$$

where $\mathrm{k}$ is the permeability, $\rho$ is the fluid density, $\mathrm{g}$ is gravity and $\mu$ is the fluid viscosity. 
The fit of the model to the excess flow data is shown in Figure 6. The fit is based upon a value for the hydraulic diffusivity, c, of $3700 \mathrm{~cm}^{2} / \mathrm{sec}$, and a value for $\mathrm{L}$ of $2000 \mathrm{~m}$. The model is able to mimic the magnitude and decay characteristics of the streamflow. However, the model is unable to mimic the magnitude of the groundwater response. The model would indicate that water table drops in the high elevation regions would be $180 \mathrm{~m}$ rather than the observed drops of tens of meters. This discrepancy may reflect the inappropriateness of the assumed length scale, $\mathrm{L}$. It also indicates that this model is too simplistic to provide for more than a first order description of the hydrologic response.

\section{CONCLUSIONS}

This study has focused on the groundwater and surface water response of two basins to the Loma Prieta earthquake. Because streamflow in the San Lorenzo River is monitored extensively, and because the Santa Cruz mountains contain numerous land owners who utilize groundwater supplies, the hydrologic response can be examined in some detail. The signature of the hydrologic response is one which is consistent with earthquake enhanced groundwater flow paths.

The enhancement of groundwater flow paths may also be responsible for hydrologic changes seen in response to other earthquakes. This mechanism may explain why the general response of streams to earthquakes is one of increased flow. Because streams are usually the exit area for groundwater flow, any enhanced groundwater motion would be readily detected in the base flow signature of the stream. For order of magnitude increases in permeability to produce identifiable streamflow response, base flow must be a significant contributor to the stream. In addition, the permeability increases must either be areally extensive or occur in key locations.

The hydrologic response suggests that the shallow materials in the highlands areas of these basins are in a state of incipient failure. Dynamic or static shear strains produced by both the Loma Prieta and Lake Elsman earthquake are large enough to generate new cracks and microfractures in the upper 200-300 m of the crust. The fractures generated must be able to form a new continuous flow path or enhance an old continuous flow path. The weak nature of the near surface is evident by the numerous active and ancient landslides in the area. It can also be inferred from the pervasive control fracture permeability had on the pre-earthquake state of groundwater flow in the region. This area has been subjected to repeated earthquakes and it is likely that seismic events, both historic and prehistoric, have had a large impact on the geologic evolution of permeability and groundwater flow paths in the region. 


\section{ACKNOWLEDGMENTS}

We thank the members of the South Skyline Homeowners Association for their cooperation. Robert Golling of the Santa Cruz Flood Control and Water Conservation District provided the stream chemistry data. The precipitation data was collected by the Santa Clara Valley Water District. John Hem, K. Michael Nolan and Arthur Lachenbruch provided helpful comments and suggestions on an earlier version of this manuscript. 


\section{REFERENCES CITED}

Akers, J. P., and Jackson, L. E. Jr., 1977, Geology and ground water in western Santa Cruz county, California, with particular emphasis on the Santa Margarita sandstone, U. S. Geological Survey Water Resources Investigations 77-15, 7p.

Bell, J. W., and Katzer, T., 1987, Surficial geology, hydrology, and late quaternary tectonics of the Ixl canyon area, Nevada, Nevada Bureau of Mines and Geology Bulletin 102, 52p.

Bower, D. R., and Heaton, K. C., 1978, Response of an aquifer near Ottawa to tidal forcing and the Alaskan earthquake of 1964, Canadian Journal of Earth Science, 15, p. 331-340.

Brace, W. F., 1980, Permeability of crystalline and argillaceous rocks, International Journal of Rock Mechanics and Mineral Science, v. 17, p. 241-251.

Brace, W. F., 1984, Permeability of crystalline rock: New in situ measurements, Journal of Geophysical Research, v. 89, p. 4327-4330.

Bredehoeft, J. D., Cooper, H. H. Jr., Papadopulos, I. S., and Bennett, R. R., 1965, Seismic fluctuations in an open artesian water well, U. S. Geological Survey Professional Paper 525-C, p. 51-57.

Briggs, R. C., and Troxel, H. C., 1955, Effects of the Arvin-Tehachapi earthquake on spring and stream flows, in Oakeshott, G. B., ed., Earthquakes in Kern County, California, during 1952, California Division of Mines and Geology Bulletin 171, p. 81-97.

Carnegie Institution of Washington, 1908, The California earthquake of April 18, 1906, Report of the State Earthquake Investigation Commission, Carnegie Institute, Washington, D. C., p. 402-409.

Clark, J. C., 1981, Stratigraphy, paleontology, and geology of the central Santa Cruz Mountains, California coast ranges, U. S. Geological Survey Professional Paper $1168,51 \mathrm{p}$.

Cooper, H. H. Jr., Bredehoeft, J. D., Papadopulos, I. S., and Bennett, R. R., 1965, The response of well-aquifer systems to seismic waves, Journal of Geophysical Research, v. 70, p. 3915-3926.

Eaton, J. P., and Takasaki, K. J., 1959, Seismological interpretation of earthquakeinduced water-level fluctuations in wells, Bulletin of the Seismological Society of America, v. 49, p. 227-245.

Hector, S. T., 1976, Environmental geology of the castle rock ridge area, Santa Cruz Santa Clara Counties, California, M.S. thesis, University of California at Davis, 98 p.

Johnson, M. J., 1980, Geology and ground water in north-central Santa Cruz County, California, U. S. Geological Survey Water Resources Investigations 80-26, 33 p.

Kranz, R. L. and J. D. Blacic, 1984, Permeability changes during time dependent deformation of silicate rock, Geophysical Research Letters, v. 11, p. 975-978. 
La Rocque, G. A. Jr., 1941, Fluctuations of water level in wells in the Los Angeles basin, California, during five strong earthquakes, 1933-1940, American Geophysical Union Transactions, v. 22, p. 374-386.

Lisowski, M., Prescott, W. H., Savage, J. C., and Johnston, M. J., 1990, Geodetic estimate of co-seismic slip during the 1989 Loma Prieta, California, earthquake, Geophysical Research Letters, v. 17, p. 1437-1440.

Liu, L. B., Roeloffs, E., and Zheng, X. Y., 1989, Seismically induced water level fluctuations in the Wali well, Beijing, China, Journal of Geophysical Research, v. 94, p. 9453-9462.

Markham, K. L., Palmer, J. R., Shelton, W. F., and Trujillo, L. F., 1988, Water resources data California water year 1988, volume 2: Pacific slope basins from arroyo grande to Oregon state line except Central valley, U. S. Geological Survey Water Data Report CA-88-2, 328 p.

Nolan, K. M, Marron, D. C., and Collins, L. M., 1984, Stream channel response to the January 3-5, 1982 storm in the Santa Cruz mountains, west central California, U. S. Geological Survey Open File Report 84-248, 48 p.

Nur, A., 1974, Matsushiro, Japan earthquake swarm: confirmation of the dilatancy- fluid diffusion model, Geology, v. 2, p. 217-221.

Rantz, S. E., 1971, Mean annual precipitation and precipitation depth-duration frequency data for the San Francisco Bay region, California, U. S. Geological Survey OpenFile Report, $23 \mathrm{p}$.

Sibson, R. H., 1981, Fluid flow accompanying faulting: field evidence and models, in Earthquake Prediction, Simpson, D. W., and P. G. Richards eds., Maurice Ewing Series 4, p. 593-603.

Steele, T. D., 1968, Seasonal variations in chemical quality of surface water in the Pescadero creek watershed, San Mateo County, California, Ph.D. dissertation, Stanford University, $179 \mathrm{p}$.

Sylvester, M. A., and Covay, K. J., 1978, Stream quality in the San Lorenzo River basin, Santa Cruz County, California, U. S. Geological Survey Water Resources Investigations 78-19, $61 \mathrm{p}$.

Waller, R., 1966, Effects of the March 1964 Alaska earthquake on the hydrology of southcentral Alaska, U.S. Geological Survey Professional Paper 544-B, 28 p.

Whitehead, R. L., Harper, R. W., and Sisco, H. G., 1985, Hydrologic changes associated with the October 28, 1983, Idaho earthquake, Pure and Applied Geophysics, v. 122, p. 280-293.

Wood, S. H., Wurts, C., Lane, T. Ballenger, N., Shaleen, M., and Totorica, D., 1985, The Borah Peak, Idaho earthquake of October 28, 1983 - hydrologic effects, Earthquake Spectra, v. 2, p. 127-148. 